\title{
CONTRIBUTION OF AGRICULTURE SECTOR TO NATIONAL ECONOMY IN NEPAL
}

Santosh Adhikari ${ }^{1}$

\section{ABSTRACT}

Agriculture is the mainstay of majority of Nepalese people which provides employment, foods and shelter. However, the investment in agriculture in not encouraging, received only about 3 percent of total government outlays during 2002 to 2014. In the study, Gross Domestic Product was regressed with Domestic Savings, Government Expenditure on Agriculture and Foreign Direct Investment on Agriculture with the data from FY 2002/ 03 to 2014/ 15. Regression reveals the degree of association among these variables is significant at $5 \%$ level of significance $(R=0.991, P=0.005<0.05)$. The analysis showed that the contribution of Government Expenditure on Agriculture to Gross Domestic Product was found significant whereas the Domestic Savings and Foreign Direct Investment on Agriculture were found insignificant. The compound annual growth rate of Government's expenditure was found slightly lower than that of budget allocated to Ministry of Agricultural Development. In sum, the study concluded that the Government Expenditure on Agriculture is crucial for the national economy.

Key words: Expenditure on Agriculture, Domestic Savings, FDI, GDP

\section{INTRODUCTION}

Agriculture has been an important sector in the national economy for most of the developing countries (Mongues, et al, 2012) while it plays an important role in virtually in all social and economic activities of any country (Lawal, 2011). However, Cervantes-Godoy and Dewbre (2010) found that people in developing countries who depend on agriculture for their living are typically much poorer than people who work in other sectors of the economy and that they represent a significant share, often the majority, of the total number of poor people in the countries where they live in thirty years. Agriculture sector can contribute to employment, food security and raw materials for agro-based industries. In Nepal, agriculture has been contributing to more than 70 percent households (CBS, 2013), 66 percent employment (MoAD, 2015) and 35.12 percent share to National Gross Domestic Product (GDP) (MoF, 2014). Thus, agriculture is regarded as a major contributor to the national economy as well as individuals' livelihood. A strong and efficient agricultural sector would enable a country to feed its growing population, generate employment, earn foreign exchange and provide raw materials for agro-based industries. Agriculture sector has multiplier effect on any nation's socio-economic and industrial fabric because of its multifunctional nature (Ogen, 2007; MoF, 2014) however it is affected by favorable/unfavorable climatic conditions, resulting in the fluctuation of GDP thereby

\footnotetext{
${ }^{1}$ Agri-Economist, MoAD, +977-9841787274, santoshadhikari80@gmail.com
} 
affecting overall economic growth (MoF, 2014). In this context, American Economist Walt Whitman Rostow (1960) in his Stages of Economic Growth explained that Agriculture is crucial for the "take-off stage" of nation's economic growth and development (Izuchukwu, 2011).

Government of Nepal (GoN) has realized the importance of agriculture and has prioritized in its plans, policies, and annual budget and programs since last three years. The MoAD reports states that every year budget under MoAD has increased substantially. However, the organized development of Nepal started along with the periodic plans after 1996. The first periodic plan has emphasized agriculture both as immediate action and laying of foundation for future progress and allocated Rs. 12 million to the agriculture out of Rs. 330 million (NPC, 1956). It was only in fifth plan (1975-80) which has prioritized agriculture sector and celebrated 2032 BS as agriculture year. Ninth periodic plan (1997-2002) is also important period for the agriculture sector. During that period, a long term strategy for agriculture sector, Agriculture Perspective Plan (APP) was designed and formulated for the overall national growth through agriculture growth (Mongues et al, 2012). Similarly, during the recent Thirteen Periodic Plan (2013/14-2015/16) Agriculture sector received proportionately higher budget (Table: 1 ) amount and proportion to national budget).

Table 1: Details of budget outlay in MoAD and its share to the national budget during 2002/03 to 2014/15

\begin{tabular}{lccc}
\hline FY & $\begin{array}{c}\text { National Budget } \\
\text { (Rs., 000) }\end{array}$ & $\begin{array}{c}\text { MoAD Budget } \\
\text { (Rs., 000) }\end{array}$ & $\begin{array}{c}\text { Share of Agriculture Budget to } \\
\text { National (\%) }\end{array}$ \\
\hline $2002 / 03$ & $96,124,796$ & $2,423,526$ & 2.52 \\
$2003 / 04$ & $102,400,000$ & $2,472,945$ & 2.41 \\
$2004 / 05$ & $111,689,900$ & $2,692,284$ & 2.41 \\
$2005 / 06$ & $126,885,100$ & $3,178,473$ & 2.51 \\
$2006 / 07$ & $143,912,300$ & $3,516,279$ & 2.44 \\
$2007 / 08$ & $168,995,600$ & $4,176,853$ & 2.47 \\
$2008 / 09$ & $236,015,897$ & $5,759,500$ & 2.44 \\
$2009 / 10$ & $285,930,000$ & $7,876,587$ & 2.75 \\
$2010 / 11$ & $337,900,000$ & $10,523,526$ & 3.11 \\
$2011 / 12$ & $384,900,000$ & $12,431,084$ & 3.23 \\
$2012 / 13$ & $404,824,700$ & $12,297,141$ & 3.04 \\
$2013 / 14$ & $517,240,000$ & $21,403,127$ & 4.14 \\
$2014 / 15$ & $618,100,000$ & $23,283,178$ & 3.77 \\
\hline
\end{tabular}

Source: MoAD, Budget and Program Section, 2015 
Though MoAD received low budget, its absorption capacity is good and it is improving its absorption capacity in every successive year (Figure: 1). Five years ago, MoAD spent about 6.88 billion rupees in FY 2007/08 and its spending capacity enhanced to five years to 11.54 billion rupees in 2012/13. The share of spending out of allocated budget becoming better every year which is not less than 82 percent in all year.

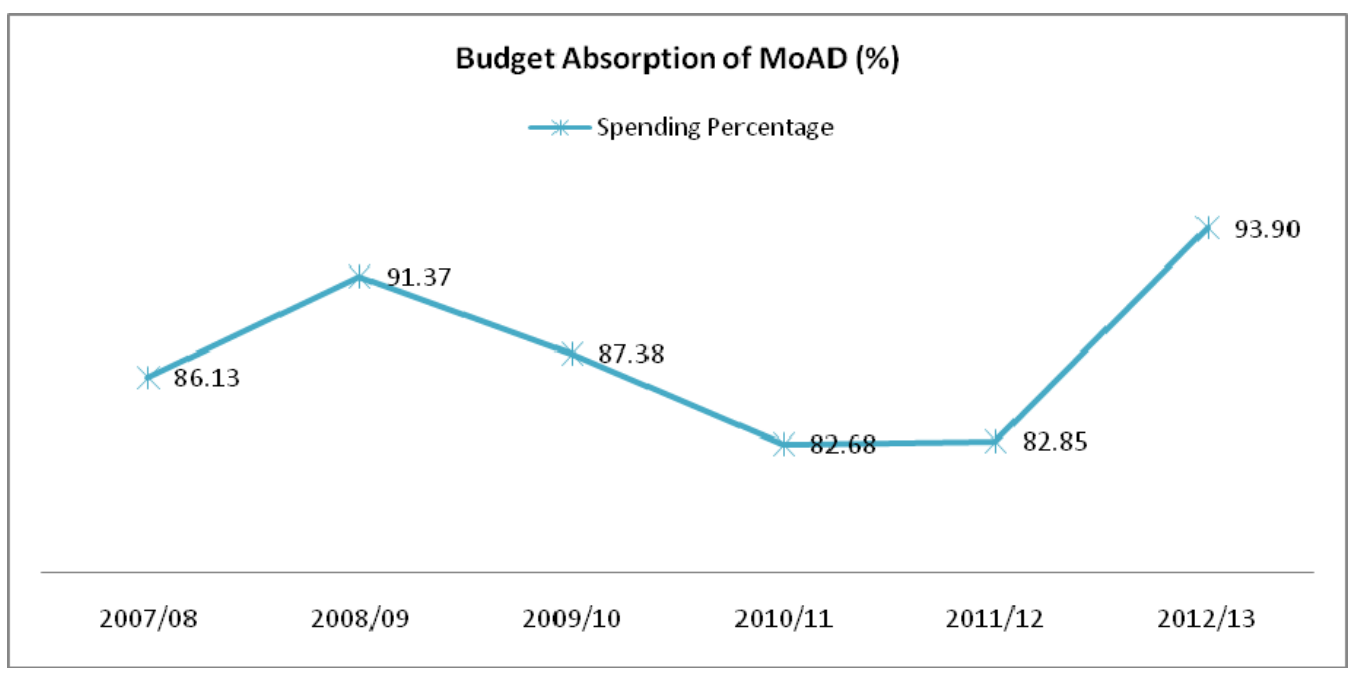

Figure 2: Trend of budget absorption (\%) by MoAD during 2007/08 to 2012/13 in Nepal Source: MoAD, Budget and Program Section, 2015

The Asian Development Bank (ADB) study revealed that there is low expenditure on agriculture indicating 4.75 percent of GDP during the first two years of TYIP (2008-10) and it is under 2 percent of GDP for the past 10 years in spite of the almost 70 percent agriculture dependent on rural population (Barrios, 2007).

Foreign aid has been important source of budget in developmental activities. The first five year periodic plan (2013-2018) had envisaged the acceptance of foreign assistances as per the complimentary budget (NPC, 1956) and developmental expenditure was completely financed by foreign aid (Gautam and Pokhrel, 2011). It continues to play an important role in socio-economic developments (MoF, 2013). Economic liberalization in Nepal after democracy in 1990 accelerated foreign assistances (Chaudhary, 2012). Now, Nepal receives such assistances from more than 40 donors officially (MOF, 2013).

Apart from the foreign aid, Foreign Direct Investment (FDI) also contributes significantly to the national economy. FDI occurs when a citizen of one county to acquires an asset to another country with the intention to manage that asset (Chaudhary, 2012). The major portion of the FDI goes to the manufacturing sector while agriculture receives lowest, i.e. 1 
percent (Adhikari, ...). Economists consider FDI as the most crucial factor in enhancing economic development and ensuring a reasonable standard of living for recipient countries of FDI (Chaudhary, 2012).

Domestic Saving is considered as the source of investment in any country. However, it is not encouraging. It is around 9 percent of GDP in FY 2070/71. (MoF, 2014).

\section{OBJECTIVE OF THE STUDY}

The purpose of this study is to review and analyze the trends and causes of change in government expenditures on agriculture and their compositions in Nepal to develop an analytical framework for determining differential impacts of various government expenditures on economic growth of Nepal.

Similarly, the study intends to find out the annual growth rate of the government expenditure on agriculture during FY 2002/03 to 2014/15.

\section{MATERIALS AND METHODOLOGY}

To study and analyze the numerical contribution of agriculture spending on National Economy, the study was conducted based on the secondary information provided by various organizations and archived from the several websites. The study collected information from The Secretariat of National Planning Commission, Ministry of Finance, MoAD, Central Bureau of Statistics and other institutes. The study focuses on the importance of spending on agriculture to the national economy and Gross Domestic Product (GDP). The information included mainly explains trend of investment to MoAD, AGDP, Domestic Savings, and Foreign Direct Investments in Agriculture.

The methodology includes the calculation of GDP at constant price of 2000/01 with the information provided on investment in agriculture, domestic savings, government expenditure on Agriculture and Foreign direct investment. The given model uses GDP as dependent variable in relation to the Domestic Savings, Government Expenditure on Agriculture and Foreign Direct Investment. Similar type of the study was also conducted by Izuchukwu in 2011 to analyse the contribution of agricultural sector on the Nigerian economic development.

The statistical formula for the given model is as follows:

\section{$G D F=\beta O+\beta 1 D S+\beta 2 G E A+\beta B F D I+\beta E$}

Where,

GDP $=$ Gross Domestic Product

DS= Domestic Savings

GEA = Government Expenditure on Agriculture

FDI= Foreign Direct Investment on Agriculture

$\mu=$ error Term 
Similarly for the calculation of the Compound Annual Growth Rate (CAGR)of National Budget and budget to MoAD following formula was used with Table 1.

$\operatorname{CAGR}=\left(P_{0} / P_{n}\right)^{1 / n}-1$

Where,

CAGR = Compound Annual Growth Rate (National budget or budget to MoAD)

$P_{0}=$ Base year value

$P_{n}=$ Present year value

$\mathrm{n}=$ Number of years

\section{RESULTS AND DISCUSSIONS}

The following table describes the regression analysis for the impact of agriculture in the Nepalese national economy, Gross Domestic Product (GDP) as dependent variable while Domestic Savings, Government Expenditure on Agriculture and Foreign Direct Investment on Agriculture are independent variables.

Table 3: Data Analysis of DS, GEA and FDI to total GDP

\begin{tabular}{|c|c|c|c|c|c|}
\hline \multirow[b]{2}{*}{ Model } & \multicolumn{2}{|c|}{$\begin{array}{c}\text { standardized } \\
\text { Coefficients }\end{array}$} & \multirow[t]{2}{*}{$\begin{array}{l}\text { Standardized } \\
\text { Coefficients }\end{array}$} & \multirow[b]{2}{*}{$\mathrm{T}$} & \multirow[b]{2}{*}{ Significant } \\
\hline & B & $\begin{array}{c}\text { Standard } \\
\text { error }\end{array}$ & & & \\
\hline (Constant) & $3.669 \mathrm{E} 8$ & $5.462 \mathrm{E} 7$ & & 6.718 & .001 \\
\hline Domestic Saving & -.259 & 1.508 & -.037 & -.172 & 0.870 \\
\hline $\begin{array}{c}\text { Government Expenditure in } \\
\text { Agriculture }\end{array}$ & 101.535 & 21.094 & 1.026 & 4.813 & .005 \\
\hline Foreign Direct Investment & 6.995 & 118.165 & .004 & .059 & 0.955 \\
\hline
\end{tabular}

$\mathrm{R}=.991$, R-square $=0.983$, Adjusted R-Square $=0.972$, standard error of the estimates $6.028^{*} \mathrm{E7}$ (not significant)

The above Table 3 reveals that Government expenditure in agriculture (101.535) is the major contributing factor for the National Economy there by affecting GDP, i.e. for every unit change in Government Expenditure on Agriculture there is a corresponding change of 101.535 units in GDP. Interestingly the Domestic Saving shows negative coefficient and both DS and FDI are insignificant to the GDP with the respective P-values $0.870>0.005$ and $0.955>0.005$. 
Table 4: ANOVA $^{\mathrm{b}}$ Table

\begin{tabular}{llllll}
\hline Model & Sum of Squares & Df & Mean Square & F & Sig. \\
\hline Regression & $1.020 \mathrm{E} 18$ & 3 & $3.400 \mathrm{E} 17$ & 93.585 & $.000 \mathrm{a}$ \\
Residual & $1.817 \mathrm{E} 16$ & 5 & $3.633 \mathrm{E} 15$ & & \\
Total & $1.038 \mathrm{E} 18$ & 8 & & &
\end{tabular}

a. Predictors: (Constant), Foreign Direct Investment, Government Expenditure in Agriculture, Domestic Saving

b. Dependent Variable: Total GDP

Table 4 shows the model shows goodness of fit and all three predictor variables i.e. Domestic Savings, Government Expenditure on Agriculture and Foreign Direct investment in Agriculture, contribute significantly to the National Economy in terms of GDP.

The $R$ value of 0.991 explains that there is highly positive relationship among the predictor variables and GDP. Similarly, adjusted $R^{2}$ value of 0.972 states that 97 percent of the variation could be explained by the three independent variables while remaining 3 percent could not be accounted for.

The value of adjusted $R^{2}(0.972)$ is close to the $R$ value $(0.991)$ explains the model is fit for making generalization. Furthermore, $\mathrm{F}=93.585$ proves the model's goodness of fit to the analyzed data.

The Compound annual growth rate analysis of National budget over 13 years from table 1 reveals that it has increased at the rate of $18.03 \%$ annually. Similarly, for budget to MoAD, it is $22.74 \%$.

\section{CONCLUSION}

The study regarding the contribution of domestic savings, government expenditure on agriculture and foreign direct investment on agriculture to the national economy reveals that these variables jointly contribute significantly thereby indicating the models goodness of fit. The study shows that government expenditure on agriculture is crucial for the GDP indicating per unit expenditure on agriculture could contribute more than 101 units to the GDP on the basis of analysis of data in the model tested. However, the government budget allocation to expenditure on agriculture is not that much interesting, receiving around 3 percent of the national budget thereby creating pressure to the ever increasing demands of farmers.

The annual budget growth rate of MOAD was found to be $22.74 \%$ which is slightly higher than that of National budget. However, to satisfy the ever increasing demand of farmers to the service delivery, it is not sufficient. 
The study has collected and analyzed as much data as available, however to come to the conclusion, it is recommended to study and analyze further time series information of many years.

\section{ACKNOWLEDGMENTS}

The author is highly indebted to Mr. Prakash Acharya, Agriculture Extension Officer at Western Regional Agriculture Directorate, Kaski, Mr. Diwas Raj Bista, Agriculture Extension Officer at Ministry of Agricultural Development, Kathmandu and Mr. Bikas Paudel AgriEconomist at Ministry of Agricultural Development, Kathmandu for their kind support and suggestions regarding data collection and analysis.

\section{REFERENCES}

Adhikari, R., __. Foreign investment in Nepal current status, prospects and challenges. SAWTEE working paper no. 01/13, South Asia Watch on Trade, Economics and Environment (SAWTEE), Kathmandu, Nepal

Barrios, E.B., 2007. Convergence in agriculture of some Asian countries, ADB Institute discussion paper No. 71. ADB Institute. Archived as ww.adb.org/sites/default/files/publication/156710/adbi-dp71.pdf

CBS, 2013. National sample census of agriculture Nepal 2011/12. National report. Government of Nepal, National Planning Commission Secretariat, Central Bureau of Statistics Kathmandu, Nepal.

Cervantes-Godoy, D. and Dewbre, J., 2010. Economic Importance of Agriculture for Poverty Reduction, OECD Food, Agriculture and Fisheries Working Papers, No. 23, OECD Publishing. doi: $10.1787 / 5 \mathrm{kmmv} 9 \mathrm{~s} 20944-\mathrm{en}$

Chaudhary, S. K., 2012. Foreign direct investment in Nepal: Current status, prospects and challenge

Gautam, M.S. and Pokhrel, B., 2011. Foreign Aid and Public Policy Process in Nepal A Case of Forestry and Local Governance. Southasia Institute of Advanced Studies, Kathmandu, Nepal. Available at http://www.sias-southasia.org/publications/foreign-aid-and-public-policy-process-innepal-a-case-of-forestry-and-local-governance/

Izuchukwu, O., 2011. Analysis of the contribution of agricultural sector on the Nigerian Economic development. Archived as http://wrbrpapers.com/static/documents/March/2011/15.\%200ji-Okoro-FINAL.pdf

Lawal, Dr. W.A., 2011. An analysis of government spending on agriculture sector and its contribution to GDP in Nigeria. International Journal of Business and Social Science, vol. No. 20, November, 2011. Archived as 
http: / /unilorin.edu.ng/publications/lawalwa/AN\%20.ANALYSIS\%200F\%20GOVT\%20SPENDING\%2 0ON\%20AGRIC.\%20SECTOR.pdf

MoAD, 2015. Ministry of Agricultural Development website: www.moad.gov.np/index.php

MoF, 2013. Foreign Aid in Nepal FY 2011-12. Government of Nepal, Ministry of Finance, International Economic Cooperation Coordination Division, Singhadurbar, Kathmandu, Nepal.

MoF, 2014. Economic survey, Fiscal year 2013/14: Government of Nepal, Ministry of Finance, Singhadurbar, Kathmandu, Nepal.

Mongues, T., Yu, B., Fan, S. and McBride, L., 2012. The impacts of public investment in and for agriculture, synthesis of the existing evidence. IFPRI discussion paper 01217. International Food Policy Research Institute, Development strategy and governance division. Archived as www.ifpri.org/sites/default/files/publications/ifpridp01217.pdf

NPC, 1956. First periodic plan (2013-2018). National Planning Commission, Nepal. Archived as http://npc.gov.np/web/new/uploadedFiles/allFiles/First\%20plan_eng.pdf

NPC, 1975. Fifth Periodic Plan (2032-2037) (Nepali) archived as http://npc.gov.np/web/new/uploadedFiles/allFiles/fifth_eng.pdf

Ogen, 0. 2007. The agricultural sector and Nigeria's Development: comparative perspective from Brazilian agro-industrial sector economy, 1960-1995. Archived on April 23, 2015. 